\section{Comment on Peter}

Lachmann's article 'Stem cell research-why is it regarded as a threat?' in EMBO reports, March 2001

Peter Lachmann, President of the Academy of Medical Sciences and Professor of Immunology at the University of Cambridge, gives us his reasons for supporting the British Government's decision of January 22, 2001, to allow therapeutic cloning in order to harvest human embryonic stem cells. He eloquently and persuasively rejects some common objections to the use of these pluripotent cells to treat a number of diseases. I agree with his medical arguments in support of stem cell therapy and with his firm stand against human cloning. I also wish to compliment him on his well-reasoned views, which are most welcome in the heated debate about the use of human embryonic stem cells.
Indeed, stem cell therapy, including the possibility of using adult stem cells, may, not now but at some time in the future, provide cures for many ailments of the aged, such as cardiovascular disease, diabetes or Parkinson's disease. But, I do not believe that stem cell therapy will change our life expectancy dramatically, although it could greatly improve our quality of life. I do not share Professor John Harris's concerns about immortality (Intimations of Immortality, 2000, Science, 288, 59), because this is too much like science fiction. Prolonging our lives by improving cardiac function or preventing diabetes of the aged will not necessarily make us young again mentally. And that is all for the better. Stem cells should not be used to manipulate the biological clock that determines our lifespans. If stem cell therapy could prolong the lifespan of humans, it would not be 'an accolade to medicine'.

What I missed in Professor Lachmann's article, however, is the acknowledgement that stem cell therapy is fundamentally different from other treatments, such as the use of antibiotics, the latest revolution in medicine. Implantation of stem cells will profoundly interfere with the regulatory circuitry of our cells and tissues. It is, therefore, not surprising to someone familiar with cellular regulation, that implantation of stem cells into the brain of Parkinson patients caused side effects that were worse than the disease itself. When we explore the possibilities of stem cell therapy, we must proceed with caution. It will not be an easy task and setbacks are to be expected. We must be aware that, by using stem cells, we can manipulate the developmental programme with which evolution has endowed us.

\section{Ernst J.M. Helmreich}

University of Würzburg, Germany

DOI: 10.1093/embo-reports/kve118 